\title{
The Case for Rainforest Foragers: The Starch Record at Niah Cave, Sarawak
}

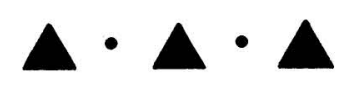

HUW BARTON

THE NATURE OF HUNTER-GATHERER OCCUPATION PATTERNS and subsistence practices within the tropics is currently poorly understood. Finding the "hard evidence" of human occupation within rainforest presents many difficulties because sites are difficult to detect and the survival rate of organic material that might shed light on subsistence strategies is extremely low. Niah Cave (Sarawak, Malaysia) provides the perfect locality to investigate evidence of past subsistence practices in tropical rainforest, because it combines a long history of human occupation dating from at least 45,000 B.P. to the early Holocene with excellent conditions of organic preservation. For some years there has been lively debate about the nature and timing of rainforest occupation in the tropics (see Bailey et al. 1989; Bailey and Headland 1991; Brosius 1991; Colvinaux and Bush 1991; Endicott and Bellwood 1991; Headland 1987; Piperno and Pearsall 1998; Townsend 1990) and uncertainty about the composition and distribution of lowland tropical rainforest during the last glacial period and glacial maximum (see this volume: Gilbertson et al.). However, one aspect of this debate in relation to humans is common throughout: Whether humans were occupying a "closed" rainforest type or a more "patchy" open type of environment, access to high-energy carbohydrate staples would have been essential. In historic times both yams (Dioscoreaceae), aroids (Araceae), and starch-rich species of palm (Palmae) have served as important sources of carbohydrate in the form of digestible starch.

In recent years it has been demonstrated that starch, contrary to expectations, can survive over long periods of time in a wide variety of contexts, including the tropics, and may be identified to species level in some cases (e.g., Barton 1991; Barton and White 1993; Briuer 1976; Loy et al. 1992; Piperno et al. 2000; Shafer and Holloway 1979; Therin et al. 1999; Ugent and Peterson 1988). The possibility that some starch can be identified at the level of genus or species therefore presents tropical archaeology with a new and powerful technique for the investigation of tropical hunter-gatherer subsistence in prehistory.

This study reports preliminary results from ongoing research on the recovery of starch from Pleistocene sediments within Niah Cave that are associated with evi- 
dence of human occupation (current work by the author is focusing on starch residues on stone tools from the excavations). The rationale for the research was the expectation that the processing and consumption of starchy foods at the site might have left a "residue" of starch incorporated and preserved within defined sedimentary horizons. Similar studies of starch in sediments from arid zone caves (Atchison and Fullagar 1998) and tropical open sites (Lentfer et al. 2002; Therin 1994) gave optimism for the likelihood of starch survival at Niah and for the viability of the proposed approach.

\section{PLEISTOCENE ENVIRONMENTS AT NIAH}

The current vegetation surrounding Niah Cave is primarily mixed dipterocarp forest, with a mixture of primary rainforest and disturbed secondary forest associated with areas of abandoned agriculture (Hazebroek et al. 2001:226). The limestone of the Gunong Subis that contains the Niah Cave and its complex of caverns is itself a striking formation of sheer-sided craggy limestone walls towering nearly $400 \mathrm{~m}$ above the surrounding lowland rainforest of the present-day Niah National Park. The limestone hills support their own diverse plant community of more than 600 species (Anderson 1965), filling a variety of microhabitats such as scree slopes, fissures, and shaded gullies. The climatic classification of the Niah region is tropical superwet, with a mean annual rainfall in excess of $3000 \mathrm{~mm}$ and where dry periods longer than a month are rare or even absent in some areas (Richards 1996:162).

During the Last Glacial Maximum (LGM) temperatures may have dropped $2-7^{\circ} \mathrm{C}$ (Flenley 1998:49; Sun et al. 2000:310), lowering the lower montane rainforest boundary by ca. $1000 \mathrm{~m}$ to a height of ca. $150 \mathrm{~m}$ above the contemporary sea level (Flenley 1998:192). Changes in the summer monsoon may have created large areas of dry seasonal and savannah forest in southern Borneo (Heaney 1991 : 57). However, changes to the environment immediately surrounding Niah (situated as it is to the north of the band of proposed seasonal and savannah forest) are not clear, as there are few lowland records from the region. A pollen core from a lowland peat swamp in West Kalimantan indicates drier conditions during the LGM, but cannot resolve whether the climate was wetter or drier than present prior to this period (Anshari et al. 2001). The distance of the sea from the cave mouth during the late glacial period is also not confidently known at present, but, assuming no major plate movement, may have been up to about $30 \mathrm{~km}$ from ca. 50,000 years ago and up to ca. $100 \mathrm{~km}$ at the LGM (Voris 2000). Offshore pollen cores on the Sunda Shelf imply that, though the climate cooled during the LGM, it remained wet. Vegetation on the newly exposed land mass consisted of lowland tropical rainforest, with mangroves along the coast and river deltas. The record is also characterized by occasional influxes of pollen from lowland montane rainforest (Sun et al. 2000:311-313).

The range of fauna recovered from the late Pleistocene levels at Niah suggests that humans were foraging in a mosaic of closed forest, scrub, grassland, swamp, and freshwater lakes or rivers (Cranbrook 2000:83). Preliminary analyses of later Holocene deposits also reflects a relatively generalized subsistence base (Barker et al. 2002:160), though ongoing analysis may change this picture. 
In total, 94 soil samples from three main deposits within the cave were analyzed: an excavated baulk within the Hell Trench (57 samples) and two areas at the rear of the cave (Area A) termed Block A (21 samples) and Block B (16 samples) (for locations, see this volume: Barker, Fig. 2). The Hell Trench sequence investigated is associated stratigraphically with the location of the famous Deep Skull found by the Harrissons in 1958, and has been dated at the top to ca. 40,000 B.P. (Barker et al. 2001; and see this volume: Barker, Figs. 3 and 5). Basal dates are not yet available, but a stone flake found near the base of our own excavations in the Hell Trench indicates that human occupation began earlier still. The Area A sediments are later, but also Pleistocene in date; the top of Block A is not yet dated but contains a mid-sequence radiocarbon determination of $27,960 \pm 200$ B.P. (context 1025; the radiocarbon dates cited in this paper are uncalibrated), and the Block B sequence is bracketed by dates of 19,650 \pm 90 B.P. near the base (context 1020 ) and 8,630 \pm 45 в.P. (context 1015) at the top. Both sediments belong to what is classified in the site stratigraphy as Unit 4, a mixture of brown-silt sands with wood ash, charcoal, and guano flecks and various layers of laminated ash and guano, notably rich in animal bone, ash and charcoal, and mollusks (Barker et al. $2002: 158$ ).

Soil samples were initially sieved to remove the coarse fraction, then two $5 \mathrm{~g}$ samples were taken from each sedimentary unit. The lightest fraction of organics and minerals was removed using a low-density solution of sodium polytungstate, and the starches and any other material with a specific gravity less than 1.5 were then removed in a high-density solution. At the end of the extraction process, the final sediment was resuspended in $500 \mathrm{ml}$ of ultra-pure water, from which a $50 \mathrm{ml}$ aqueous sample was removed by pipette. The extract was left to air dry on a covered glass slide and mounted with glycerine.

The starch grains were recorded using a combination of size and morphological characteristics. Maximum length and width were recorded using an eyepiece micrometer, and most shape and other attributes were recorded at $200-1000 \times$ magnifications. Starch grains are three-dimensional objects, and to ensure that accurate shape identification is made it is highly desirable to try to rotate the grains beneath the coverslip. The determination of size and/or shape alone will not be sufficient to enable accurate identification in most cases, as overlap does exist between species. However, when combined with a more detailed assessment of the morphological characteristics of granules, such as surface features, color, hilum position, hilum features, and the number and nature of granule facets, a higher level of taxonomic identification is possible (e.g., Loy et al. 1992; Piperno and Pearsall 1998).

Accurate identification of starch grains in archaeological deposits depends on comparison with modern starches. This study has focused on the identification of starchy roots and some palms known or thought likely to have occurred within the vicinity of Niah Cave. The present Southeast Asian reference collection at the University of Leicester is not exhaustive by any means, but represents what could be put together with voucher specimens from botanic gardens (such as the Royal Botanic Gardens, Kew, in London), various herbaria, and limited field collection in Borneo. The Kew herbarium was a particularly useful source of ma- 
terial, for the tuber samples accompanying leaf material on the herbarium sheets, even though dry and woody (they were mostly collected between 1916 and 1964), still contained identifiable granules. The oldest starches in the Leicester collection come from Kew's Economic Botany Collection, with preserved starches recovered from samples of dried tissue or flour collected in the field as early as 1856 .

\section{RESULTS}

A total of 201 starch granules was recovered from the initial screening of the deposits (Table 1). Starch granules were not recovered from all slide samples processed. Eleven samples (52 percent) from Area A Block A produced starch, six samples (38 percent) from Area A Block B, and 25 samples (44 percent) from the Hell Trench. Generally, only a few granules were recovered from each $50 \mathrm{~g}$ soil sample, though one slide yielded 100 granules (the limit of counting per slide). Recovery rates therefore seem quite low, but it has to be emphasized that we are at the early stages of developing this technique, still refining experimental extraction protocols and learning about the different conditions that might influence preservation. Associated with the starch granules on most slides were other wellpreserved organic remains, including intact cellular plant tissue. A total of 155 granules could be assigned to types or groups with distinctive morphologies (Table 2); 44 granules, round grains of various sizes, could not be assigned because they may belong to a wide range of plant taxa.

The frequency of starch counts is too low to discuss anything other than presence and absence - the assessment of the frequency or diversity of activity lies beyond recovery rates at this time. However, even though the absolute numbers of grains are low, the high diversity of granule morphology indicates that a wide range of starchy plants was deposited at Niah Cave over time. Moreover, the granules are relatively large in size, ranging from $15 \mu \mathrm{m}$ to $75 \mu \mathrm{m}$, and are all within the size range of "storage" starch-that is, starch derived from tubers, roots, fruits, and nuts rather than from leaves and stem tissue.

In general starches were recovered as isolated granules, but some clusters of starch were found: groups of more than two granules occurring as a tight clump, sometimes associated with fragments of cellulose tissue, that are likely to be derived from a single plant source (Fig. 1). The largest cluster (Type 1), found in Area Block A context 1034, consisted of two large, flattened grains $(33-50 \mu \mathrm{m})$ and number of small subround grains $(1.5 \mu \mathrm{m})$. A second starch cluster (Type 2) of four polygonal granules $(15-20 \mu \mathrm{m})$ was recovered from lower down Block A in context 1023. The plant source of both clusters is presently unknown. A third very large cluster of material comprising of hundreds of small polygonal grains (ca. $1-2 \mu \mathrm{m})$ is not definitely starch as the material is not birefringent under crosspolarized light, but the grains have the morphology of Dioscorea hispida (Asiatic bitter yam) or D. esculenta (Lesser yam). The largest sample of single granules certainly derived from the same plant source was Type 3, recovered from Area A Block A context 1034. These granules $(2-10 \mu \mathrm{m})$ occur in hundreds on two slide mounts prepared sequentially, indicating that this material probably derived from a single lump of starchy residue preserved in the sediments that was broken up during the extraction process. 


\begin{tabular}{|c|c|c|c|c|c|c|c|c|c|c|c|c|c|c|c|c|c|}
\hline EXCAVATION AREA & $\begin{array}{l}\text { CONTEXT } \\
\text { NUMBER }\end{array}$ & $\begin{array}{l}\text { RADIOCARBON AGE } \\
\text { UNCAL. B.P. }\end{array}$ & 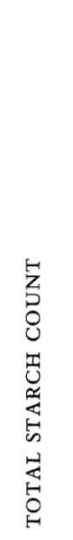 & 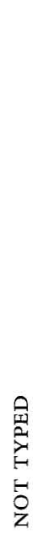 & 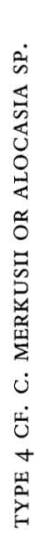 & 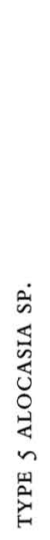 & 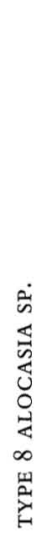 & 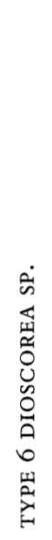 & 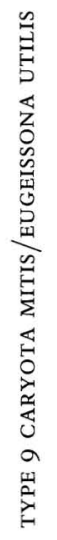 & 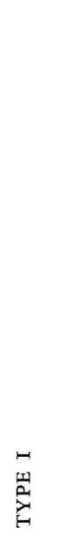 & 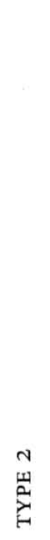 & 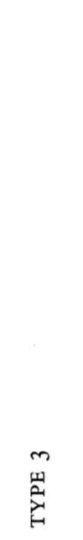 & 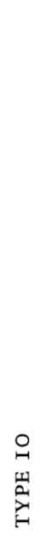 & 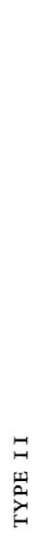 & 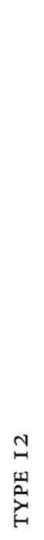 & $\begin{array}{l}m \\
\stackrel{H}{0} \\
\vec{n}\end{array}$ & 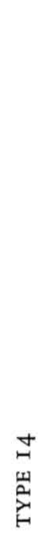 \\
\hline Hell & No number & & 3 & 2 & & & & & & & & & 1 & & & & \\
\hline Hell & 3112 & & 2 & 2 & & & & & & & & & & & & & \\
\hline Hell & 3128 & & 2 & & & & 2 & & & & & & & & & & \\
\hline Hell & 3129 & & 6 & & & 1 & 5 & & & & & & & & & & \\
\hline Hell & 3130 & ca. 40,000 & 1 & & & & & & 1 & & & & & & & & \\
\hline Hell & 3131 & & 1 & & & & & & 1 & & & & & & & & \\
\hline Hell & 3134 & & 7 & 3 & & & & & 2 & & & & & & & & 5 \\
\hline Hell & 3136 & & 10 & 5 & & & & & 1 & & & & & & & 2 & 2 \\
\hline Hell & 3137 & & 10 & 6 & & & & 2 & 1 & & & & & & & 1 & \\
\hline Hell & 3138 & & 1 & & & & & & 1 & & & & & & & & \\
\hline Hell & 3140 & & 1 & 1 & & & & & & & & & & & & & \\
\hline Hell & 3143 & & 4 & 3 & & & & & 1 & & & & & & & & \\
\hline Hell & 3150 & & 2 & 2 & & & & & & & & & & & & & \\
\hline Area A Block A & 1034 & & 115 & 5 & & 1 & & 2 & 1 & 6 & & $100 \mathrm{~s}$ & & & & & \\
\hline Area A Block A & 1033 & & 3 & 1 & 1 & 1 & & & & & & & & & & & \\
\hline Area A Block A & 1027 & & 2 & & 2 & & & & & & & & & & & & \\
\hline Area A Block A & 1025 & $27,960 \pm 200$ & 2 & 2 & & & & & & & & & & & & & \\
\hline
\end{tabular}




\begin{tabular}{|c|c|c|c|c|c|c|c|c|c|c|c|c|c|c|c|c|c|}
\hline Area A Block A & 1023 & & 4 & & & & & & & & 4 & & & & & & \\
\hline Area A Block A & 1086 & & 4 & 1 & 2 & 1 & & & & & & & & & & & \\
\hline Area A Block B & 1015 & $8,630 \pm 45$ & 5 & 2 & & & & & & 1 & & & & & 2 & & \\
\hline Area A Block B & 1016 & & 5 & 4 & & & & & & & & & & & & 1 & \\
\hline Area A Block B & 1018 & & 3 & 2 & & & & & & & & & & & & 1 & \\
\hline Area A Block B & 1019 & & 4 & 3 & & & & & & & & & & & 1 & & \\
\hline \multirow{3}{*}{$\begin{array}{l}\text { Area A Block B } \\
\text { Area B } \\
3204\end{array}$} & 1020 & $19,650 \pm 90$ & 1 & & & & 1 & & & & & & & & & & \\
\hline & & & $(100)$ & & & & & & & & & & & $100 \mathrm{~s}$ & & & \\
\hline & & Total & 201 & 44 & 5 & 4 & 8 & 4 & 9 & 101 & 4 & 6 & 1 & & 3 & 5 & 7 \\
\hline
\end{tabular}


Table 2. Type Categories of Starch Grains Defined at Niah

\begin{tabular}{|c|c|c|c|c|c|c|c|}
\hline TYPES & TAXONOMIC GROUPING & SIMPLE SHAPE CATEGORY & GRANULE FORM & SIZE RANGE $(\mu \mathrm{m})$ & MEAN SIZE (l) & HILUM POSITION & COUNT \\
\hline 4 & $\begin{array}{l}\text { Alocasia sp. \& } \\
\text { Cyrtosperma merkusii. }\end{array}$ & Sub-round & Single & 1520 & 17 & Centric & 5 \\
\hline 5 & Alocasia sp. & Bullet & Single & $23-25$ & 24.5 & Eccentric & 4 \\
\hline 8 & Alocasia sp. & Round & $\begin{array}{l}\text { Single, semi- } \\
\text { compound }\end{array}$ & $18-35$ & 24.8 & Eccentric & 8 \\
\hline 6 & Dioscorea sp. & Ovate & Single & $20-45$ & 34.5 & $\begin{array}{l}\text { Highly eccentric, } \\
\text { eccentric }\end{array}$ & 4 \\
\hline 9 & $\begin{array}{l}\text { Caryota mitis/ } \\
\text { Eugessonia sp. }\end{array}$ & Ovate & Single & $28-60$ & 45.2 & Highly eccentric & 9 \\
\hline $1^{\mathrm{a}}$ & Unknown & Round, sub-round & Single (clustered) & $1.5-75$ & $61,1.5$ & Centric & 7 \\
\hline 2 & Unknown & Polygonal & Single (clustered) & $15-20$ & 16.2 & Centric & 4 \\
\hline 3 & Unknown & Round, sub-round & $\begin{array}{l}\text { Single, semi- } \\
\text { compound }\end{array}$ & $2-10$ & 7.5 & Centric & $100 \mathrm{~s}$ \\
\hline 10 & Unknown & Sub-ovate & Single & & 55 & Highly eccentric & 1 \\
\hline $11^{\mathrm{b}}$ & Unknown & Polygonal & Single (clustered) & $1-2$ & 2 & Not visible & $100 \mathrm{~s}$ \\
\hline 12 & Unknown & Sub-ovate & Single & $20-30$ & 25 & Centric & 3 \\
\hline 13 & Unknown & Bean & Single & $18-30$ & 24.8 & Centric & 5 \\
\hline 14 & Unknown & Sub-round, disc & Single & $15-25$ & 21.8 & Centric & 7 \\
\hline
\end{tabular}

${ }^{a}$ Type 1 consists of a distinct cluster of granules on one slide with two distinct shapes, very large round granules (mean $61 \mu \mathrm{m}$ ) and very small sub-round granules (mean $1.5 \mu \mathrm{m}$ ).

${ }^{\mathrm{b}}$ Not yet fully determined if this group is starch. It appears similar to Dioscorea hispida or D. esculenta but the archaeological granules are not birefringent. 


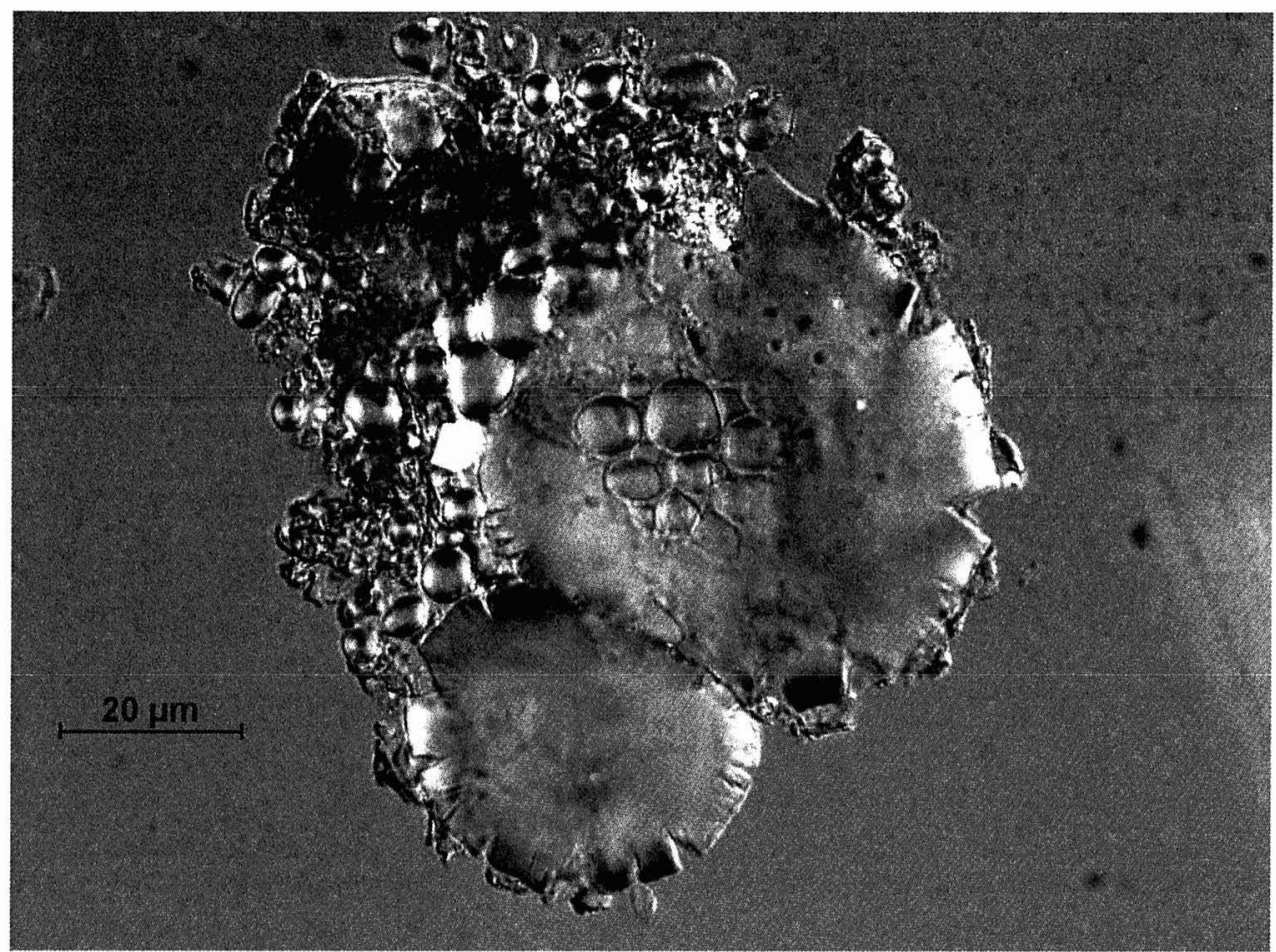

Fig. 1. Starch cluster: Type 1 granules (Area A Block A, context 1034, ms0011a).

While the recovery of ancient well-preserved starch grains from the Niah Cave deposits is in itself remarkable, of most interest are those granules that can be assigned to a taxonomic category. After all, the presence of plant material in sediments used by hunter-gatherers and on the surface of stone tools is unsurprising: the real value of these techniques lies in their ability to inform us about the particular plants used in the past. At the present time, Types 1, 2, 3, 10, 11, 12, 13, and 14 fall outside the reference database, but Types 4, 5, 6, 7, 8, and 9 fall into three groups identified to the genus level: Alocasia (aroid), Dioscorea (yam), and Caryota/Eugeissona (palm).

\section{Alocasia sp (Longiloba Complex), cf. Cyrtosperma merkusii}

Type 4 starch grains are medium-sized round grains (mean diameter $17 \mu \mathrm{m}$ ) with a centric hilum and distinct twin or triple surface facets that are slightly concave (Fig. 2). These five granules resemble reference material of Cyrtosperma merkus collected within the secondary rainforest of Niah National Park, but also share some characteristics with an unidentified species of Alocasia (Species C, possibly Alocasia lowii) also found within the park. Both plants were found within a zone of previously disturbed secondary rainforest. Species C was identified by Iban informants as birah, an Iban word that, according to Richards (1981), generally refers to any aroids that contain poisonous juice or cause itchiness. It may often be applied to the giant taro Alocasia macrorrhiza, though the same Iban informants 


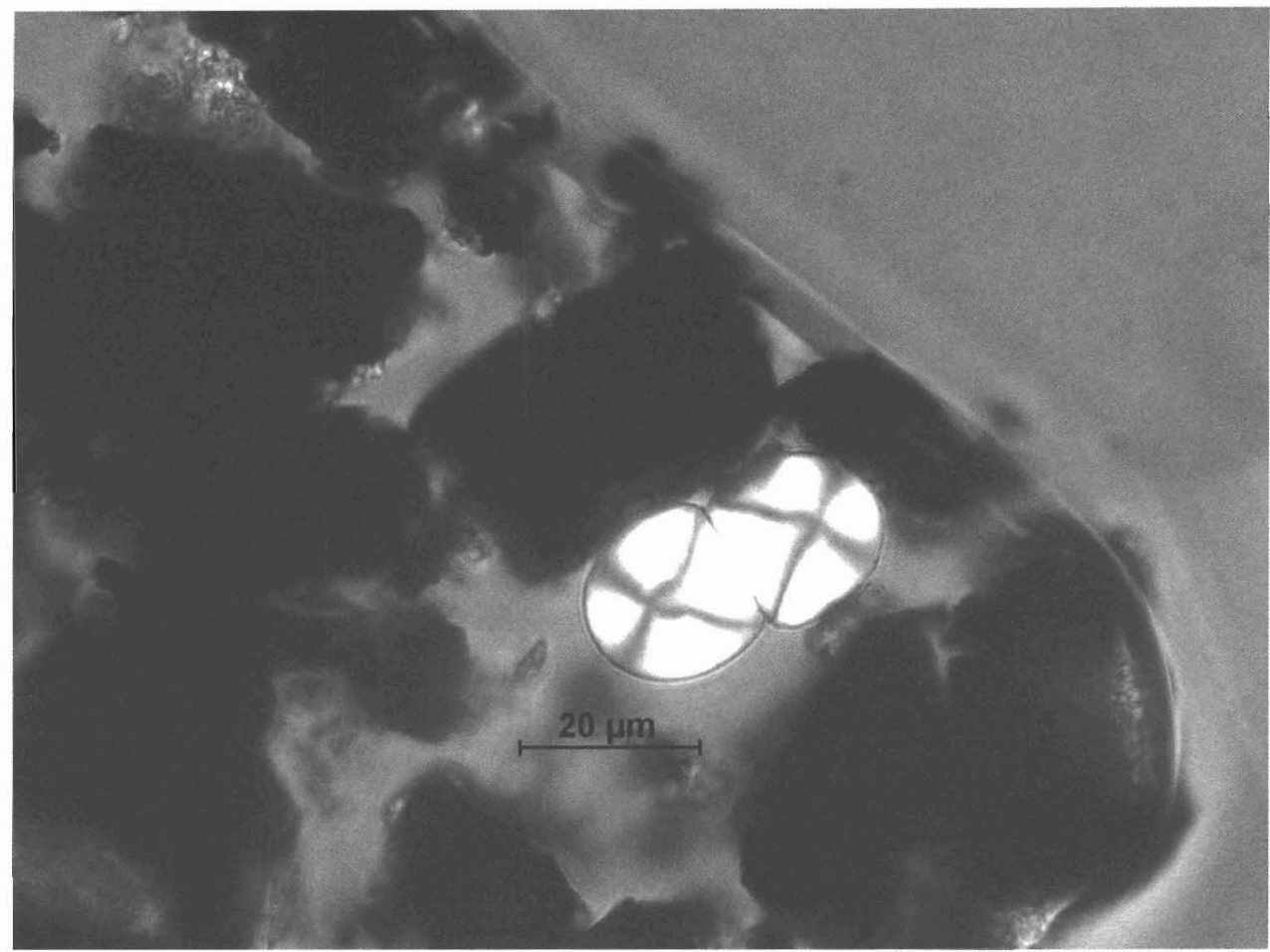

Fig. 2. Type 8 granule, semi-compound Alocasia sp. grain (Hell Trench, context 3129, ms0055).

repeatedly refer to the latter plant as jegong, a word that may be recently borrowed as it does not appear in any Iban-English dictionary, nor in Burkill (1966). At least two aroids of the Longiloba Complex, $A$. denudata and $A$. lowii, are recognized for their toxic properties, and the extract from $A$. denudata is recorded as a dart poison (Burkill 1966:107). Type 5 starch grains have very distinct morphology, resembling a squat bullet. The hilum tends to be eccentric and appears as a very small vacuole or a simple crack. The distal end of the grain is a concave depression that is quite marked and may have a slightly sinuous appearance in profile. These granules were found to occur in three species of forest Alocasia (Species C, D, and E). Type 8 granules are large round grains up to $35 \mu \mathrm{m}$ in diameter with a slightly eccentric hilum and very pronounced lamellae or growth rings; other features on two granules include a single crack running from the hilum to the perimeter of the grain, though this may be an artifact of the extraction and mounting procedure resulting from rapid rehydration. A single example of a large semi-compound grain $(17.5 \mu \mathrm{m})$ was also recorded. These granules very closely matched examples from two forest Alocasia (Species D and E) recorded in the lowland dipterocarp rainforest of Niah National Park.

\section{cf. Dioscorea alata}

Type 6 (formerly Types 6 and 7) are large ovate granules (mean $34.5 \mu \mathrm{m}$ ) with eccentric to highly eccentric hila (Fig. 3). The hilum itself is not visible in bright- 


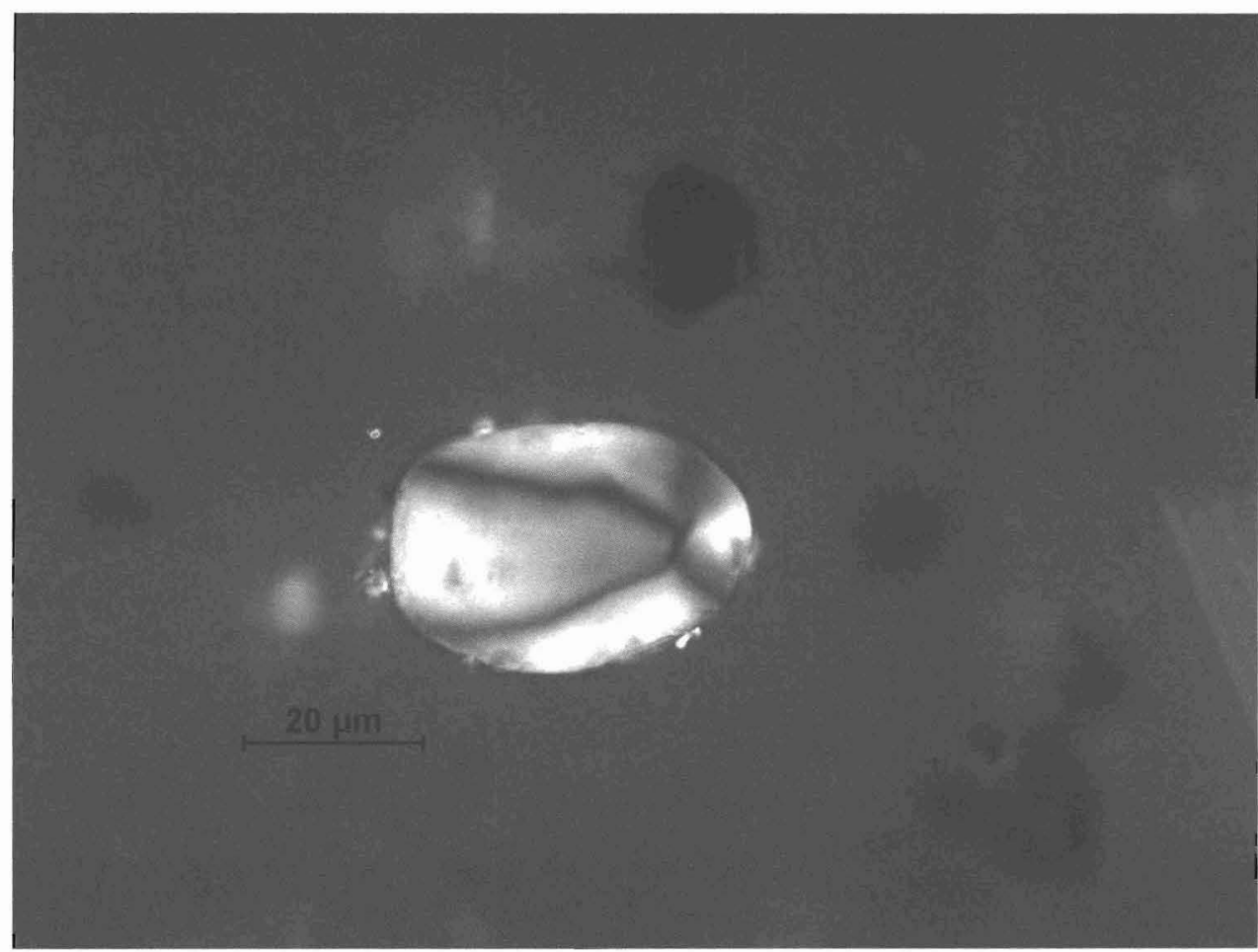

Fig. 3. Type 6 granule, simple Dioscorea sp. grain (Hell Trench, context 3137, ms0059a).

field light and can only be distinguished by the position of the polarization cross. Based on the current material within the reference collection, these granules are a very close match with Dioscorea alata. While the closest yam match within my reference collection was $D$. alata, the incompleteness of the collection requires caution; D. pentaphylla is also a likely candidate. Also, there are six other native yams on Borneo for which no reference material is yet available. Dioscorea flabellifolia is known to have been used occasionally, but the economic importance of the other five (D. filliformis, D. havilandii, D. moultonii, D. ridleyi, and D. sitamiana) is unknown.

\section{cf. Caryota mitis/Eugessonia utilis}

Type 9 starch grains consist of large $(45.2 \mu \mathrm{m})$ simple ovate granules and ovates that have single or twin facets on the distal end of the grain (Fig. 4). The simple ovates share characteristics with $D$. alata grains, having a highly eccentric hilum position, but with the single exception that the hilum itself is clearly visible as a large plain or irregular vacuole. The faceted ovates have an irregular flat or $\mathrm{v}$-shaped base in profile, the hilum position is highly eccentric, and the hilum a large vacuole or open slit. These granules have a very close match with the starch grains from a sample of hill sago (E. utilis), but they also share some similarities with sago from the fishtail palm (Caryota mitis) collected by the author from Niah 


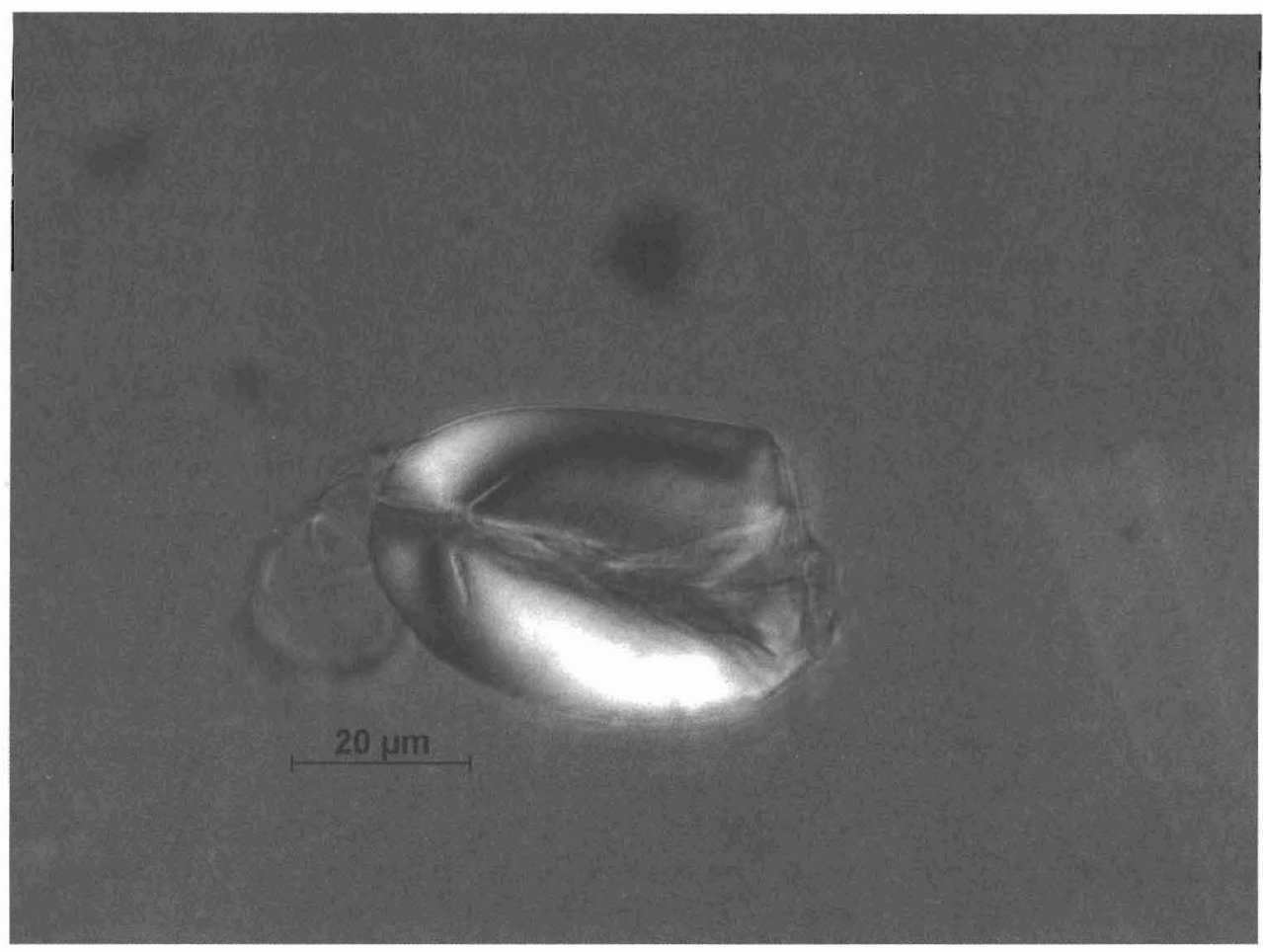

Fig. 4. Type 9 granule, simple Eugeissona utilis grain (Hell Trench, Context 3131, ms0072).

National Park. Future work is needed to clarify the identification of these palm starches.

\section{DISCUSSION}

This analysis has identified grains of aroids (Alocasia spp.) in the upper part of the Hell Trench sequence at Niah dating to younger than 40,000 B.P., and several grains of palm (Caryota mitis) and two of yam (Dioscorea sp., possibly D. alata) within and around layers older than this identified as stabilization events (Barker et al. 2002). Types 13 and 14 are also well represented in the lower levels of the Hell Trench. The sample sizes are too small and the number of samples taken from each depositional context uneven, making it difficult to draw conclusions from the vertical distributions. However, it is striking that palm starch is present from the earliest excavated levels in Hell, well below the Deep Skull levels dated to ca. 40,000 B.P., with evidence of yams following slightly later. In Block A there are aroid starches below sediments dated to $27,960 \pm 200$ B.P., and yam and sago starch grains in the uppermost layer, which at this stage is of unknown antiquity but could date to the early Holocene, judging by the date for the top of the adjacent (and stratigraphically linked) Block B. Starch grains of Alocasia spp. or Cyrtosperma merkusii, the latter an aroid still important as a food crop today, also appear to be present in layers that must date between the late Pleistocene and early Holocene. Block B does not contain any starch identified to taxo- 
nomic group, but contains a single Type 1 grain and examples of Types 12, 13, and 14. Several contexts investigated contained no starch, but due to the low numbers of grains recovered overall, it is likely that sampling alone explains their absence from these levels. The starch grains recovered from Niah may be derived from a mixture of human and nonhuman processes. Therefore, in an attempt to control for starch derived from wind- and water-borne plant material such as leaves and stem tissue, isolated granules $<5 \mu \mathrm{m}$ in size were not recorded unless they appeared as clusters or masses. Such clusters or masses are most likely to have derived from a starch storage organ, such as root or tuber tissue, and not from the leaves and stems, where starch occurs in relatively low amounts.

The presence of forest Alocasia in the deposits suggests that these species may have been collected by people for food, though botanical identification is necessary before such use can be confirmed. If these species are in fact inedible, then an alternative explanation for their presence in these deposits will be required. The possibility of tubers or rhizomes falling into the cave seems remote: the entrance to the West Mouth is raised above the forest floor and these species were not seen growing anywhere on the limestone soils of the Gunong Subis. The most likely vector to transport starch into the cave, other than humans, is the pig. The Bearded Pig (Sus barbatus) is indigenous to Borneo (Groves 2001) and found throughout the archaeological sequence at Niah (Medway 1977). The preferred diet of these pigs includes fallen fruit, roots, tubers, and other plant material (Payne et al. 1994:296). The Alocasia plants recorded in Niah National Park were all shallow-rooting species with the rhizome suspended within the spongy layer of leaf litter above the soil layer, so they are easily accessible to foraging pigs. During an informal plant survey in the Niah National Park I noted that these aroids were usually found in conditions of mixed forest canopy: some were in heavy shade; others were growing in areas of dappled sunlight but were never fully exposed to the sun.

The presence of palm and yam starch is less problematic for making inferences about human use of rainforest plants. Many species of yam are either deep rooting, such as Dioscorea alata, or, if shallow rooting, maintain very spiny roots as a defense against herbivores (Burkill 1966:812-825). There is still discussion about the status of Dioscorea alata, whether it is fully domesticated (Hahn 1995) or is in fact a true species (Lebot 1999). If from a domesticate, the starch from Niah raises major questions about the antiquity of its domestication. If it is from wild plants, it challenges current arguments about the center of its origin in either Southeast Asia (Burkill 1966:827) or the Pacific (Lebot 1999:625). With such a small quantity of starch, I am unwilling to push the case for $D$. alata being either a native plant of Borneo or an anthropogenic introduction-further work is required. The presence of Dioscorea sp. (possibly D. alata) also raises the possibility that lowland rainforest near the cave was more open and patchy in the Pleistocene than today. However, while it seems that yams such as Dioscorea grow well in areas of more open habitat, as do many edible plants, Hather (1996:545-546) argues that some yams may have derived from "closed" rather than "open" seasonal forest, with the large storage tuber and climbing vine being an evolutionary response to prolonged conditions of low light.

The sago palm (Caryota mitis) occurs within the national park and is abundant throughout the rainforest, found on the limestone and sandstone bedrock. Hill 
sago (Eugeissona utilis) is not known to occur in the national park (Kit Pearce pers. comm.) and is not a species normally recorded on limestone: it prefers poor soils, often occurring in near monospecific groves on the edges of dry ridges and scarps (Puri 1997:206; Uhl and Dransfield 1987:242). Removing the starchy pith of sago palms such as Eugeissona utilis, Arenga undulatifolia, and Caryota mitis is a labor-intensive exercise and may have required hafted tools, but energetic yields are extremely high (Ulijaszek and Poraituk 1993). The pith of several species, including Caryota mitis (Burkill 1966:477), Caryota rumphiana (Jenkins and Milton 1993:285), Caryota utan (Shuji 2002:37), and Eugeissona tristis (Burkill 1966: 973), may be eaten raw without preparation or after cooking. The antiquity of palm use by tropical hunter-gatherers is unknown. Yen (1995:836) has speculated that it has its origins in the Pleistocene, and the evidence from Niah may well support this theory.

Recent archaeological evidence of preserved starch grains on stone tools and occupation deposits from Melanesia indicates that rhizomes of Araceae were an important component of the diet of Pleistocene and Holocene foragers (Barton 1991; Barton and White 1993; Loy et al. 1992). Members of the Araceae (the family of aroids including Colocasia esculenta, Alocasia macrorrhiza, Amorphophallus paeoniifolius, and Cyrtosperma merkusii) and Zingiberaceae are shade-tolerant species adapted to living in the low-light conditions of primary rainforest. Evidence for the use of Alocasia sp. and Crytosperma sp. has been recovered from tool surfaces up to 28,000 years old in the Solomon Islands (Loy et al. 1992) and from artifacts ca. 14,000 years old in New Ireland (Barton 1991; Barton and White 1993). The presence of starchy plants has also been detected on stone tools from inland New Britain dated to around 35,000 B.P. (Pavlides and Gosden 1994). While there are as yet no available data regarding the density and distribution of these plants in tropical rainforest, they are known to be a common component of herbaceous vegetation throughout Melanesia (Richards 1996:122) and appear to have been important food plants in the past for tropical hunter-gatherers.

\section{CONCLUSION}

The results of the study of starch grains recovered from Pleistocene sediments in Niah Cave have shown the potential of this technique for investigating palaeodiet in tropical Southeast Asia. The preliminary analysis reported here has demonstrated the presence of at least fourteen definite types of starch grain within the site, of which five have been identified to the level of genus and two to species. Forest Alocasias, probably from the Longiloba Complex (see Hay 1998), currently found within lowland dipterocarp rainforest and the limestone habitat surrounding the cave, were brought into the cave at the time of the Pleistocene human occupation, probably as a result of human use though possibly through the activities of wild pigs. The yam (Dioscorea sp.) and palm sago (Caryota mitis or Eugeissona sp.) starch grains found are almost certainly a result of human foraging activities. It is clear that from the outset of human use of Niah Cave, Pleistocene hunter-gatherers already had the necessary knowledge of plant distribution in rainforest, as well as the technical knowledge, to extract useful carbohydrates from roots, tubers, and palm pith. The evidence of the starch for tuber processing is supported by the parenchyma finds from Niah (this volume: Paz) and by the in- 
terpretation of the bone tools as equipment for plant digging (this volume: Rabett). These findings, together with the evidence of aroid processing from Pleistocene contexts in Melanesia (Barton and White 1993; Loy et al. 1992), are building a picture of hunter-gatherer land use that is not consistent with the view (e.g., Bailey et al. 1989) that wet lowland rainforest was a significant obstacle to small, mobile, populations of hunter-gatherers.

\section{ACKNOWLEDGMENTS}

This research has been funded by the U.K. Arts and Humanities Research Board as part of the Niah Cave Project. I would also like to thank the Sarawak Museum in Kuching for their generous assistance, and the Malaysian government and Sarawak Biodiversity Centre in providing the necessary visas and work permits to undertake the archaeological work at Niah and botanical field collection. The Iban community from the adjacent Rumah Chang longhouse facilitated the collection of several important plant specimens from their gardens and were a continuous and enthusiastic help in wild plant identification. I am also indebted to the staff at the Herbarium in the Royal Botanic Gardens, Kew, particularly Dr. Paul Wilkins, and also to the staff at the Economic Botany Collection at Kew for voucher specimens for the starch reference collection and invaluable information regarding plant distribution and plant use. Special thanks are also due Nicholas Daby and Edmund Kurui (Sarawak Museum archaeology section) for help in language translation and field assistance, and showing me the correct way to use a parang.

\section{REFERENCES CITED}

ANDERSON, J.A.R.

1965 Limestone habitat in Sarawak. In Proceedings of the Symposium on Ecological Research in Humid Tropics Vegetation: 49-57, ed. A.J.G.H. Kostermans and F. R. Fosberg. Science Cooperation Office for S.E. Asia, Bangkok.

Anshari, Gusti, Peter A. Kershaw, and Sander van der Kaars

2001 A late Pleistocene and Holocene pollen and charcoal record from peat swamp forest, Lake Sentarum Wildlife Reserve, West Kalimantan, Indonesia. Palaegeography, Palaeoclimatology, Palaeoecology 171:213-228.

Atchison, Jennifer, and Richard Fullagar

1998 Starch residues on pounding implements from Jimnium rock-shelter. In A Closer Look: Recent Australian Studies of Stone Tools: 109-126, ed. Richard Fullagar. Sydney University Archaeological Methods Series 6. Sydney: Archaeological Computing Laboratory, Sydney University.

Bailey, C. Roger, Genevieve Head, Mark Jenike, Bruce Owen, Robert Reichtman, and Elzbieta Zechenter

1989 Hunting and gathering in tropical rainforest: Is it possible? American Anthropologist $91: 59-82$.

Bailey, C. Roger, and Thomas N. Headland

1991 Human foragers in tropical rainforest. Human Ecology 19:261-285.

Barker, Graeme, Dana Badang, Huw Barton, Paul Beavitt, Michael Bird, Patrick Daly, Chris Doherty, David Gilbertson, Ian Glover, Chris Hunt, Jessica Manser, Sue Mclaren, Victor Paz, Brian Pyatt, Tim Reynolds, Jim Rose, Garry Rushworth, and Mark Stevens

2001 The Niah Cave Project: The second (2001) season of fieldwork. Sarawak Museum Journal 56 (n.s. 77): $37-119$.

Barker, Graeme, Huw Barton, Paul Beavitt, Michafl Bird, Patrick Daly, Chris Doherty, David Gilbertson, Chris Hunt, John Krigbaum, Helen Lewis, Jessica Manser, Sue McClaren, Victor Paz, Phil Piper, Brian Pyatt, Ryan Rabett, Tim Reynolds, Jim Rose, Garry Rushworth, and Mark Stephens

2002 Prehistoric foragers and farmers in Southeast Asia: Renewed investigations at Niah Cave, Sarawak. Proceedings of the Prehistoric Society 68:147-164. 


\section{Barton, Huw}

1991 Raw Material and Tool Function: A Residue and Usewear Analysis of Artifacts from a Melanesian Rockshelter. B.A. thesis. University of Sydney, Sydney.

Barton, Huw, and J. Peter White

1993 Use of stone and shell artefacts at Balof 2, New Ireland, Papua New Guinea. Asian Perspectives 32(2): 169-181.

BRIUER, F. L.

1976 New clues to stone tool function: plant and animal residues. American Antiquity $41: 478-484$.

Brosius, Peter J.

1991 Foraging in tropical rain forests: The case of the Penan of Sarawak, East Malaysia (Borneo). Human Ecology 19:123-150.

BURKILL, I. H.

1966 A Dictionary of the Economic Products of the Malay Peninsula. Kuala Lumpur: Government of Malaysia and Singapore, Ministry of Agriculture and Cooperatives.

Colinvaux, Paul A., and Mark B. Bush

1991 The rain-forest ecosystem as a resource for hunting and gathering. American Anthropologist 93:153-162.

\section{Cranbrook, Earl of}

2000 Northern Borneo environments of the past 40,000 years: Archaeozoological evidence. Sarawak Museum Journal 55:61-109.

Endicott, K., and Peter Bellwood

1991 The possibility of independent foraging in the rainforest of peninsular Malaysia. Human Ecology 19:151-185.

Flenley, J. R.

1998 Tropical forests under the climates of the last 30,000 years. Climatic Change 39:177197.

Groves, Colin

2001 Taxonomy of wild pigs of Southeast Asia. Asian Wild Pig News 1.

HAHN, S. K.

1995 Yams. In Evolution of Crop Plants: 113-120, ed. J. Smartt and N. W. Simmonds. UK: Longman Scientific and Technical.

Hather, Jon G.

1996 The origins of tropical vegeculture: Zingiberaceae, Araceae and Dioscoreaceae in Southeast Asia, in The Origins and Spread of Agriculture and Pastoralism in Eurasia: 538-550, ed. D. R. Harris. London: University College London, Institute of Archaeology.

Hay, Alistair

1998 The genus Alocasia (Araceae-Colocasieae) in west Malaysia and Sulawesi. Gardens Bulletin Singapore $50: 221-334$.

Hazebroek, Hans. P., and Abang Kashim bin Abang Morshidi

2001 National Parks of Sarawak. Kota Kinabalu: Natural History Publications (Borneo).

Headland, Thomas N.

1987 The wild yam question: How well could independent hunter-gatherers live in a tropical rain forest ecosystem? Human Ecology 15:463-491.

Heaney, Lawrence, R.

1991 A synopsis of climatic and vegetational change in southeast Asia. Climatic Change 19:53-61.

Jenkins, Carol, and Karen Milton

1993 Food resources and survival among the Hagahai of Papua New Guinea, in Tropical Forests, People and Food: 281-293, ed. C. M. Hladik, A. Hladik, O. F. Linares, H. Pagezy, A. Semple, and M. Hadley. Paris: UNESCO.

LeBot, V.

1999 Biomolecular evidence for plant domestication in Sahul. Genetic Resources and Crop Evolution $46: 619-628$. 
Lentfer, Carol, Michael Therin, and Robin Torrence

2002 Starch grains and environmental reconstruction: A test case from West New Britain, Papua New Guinea. Journal of Archaeological Science 29:687-698.

Loy, Thomas, Mathew Spriggs, and Steve Wickler

1992 Direct evidence for human use of plants 28,000 years ago: Starch residues on stone artifacts from the northern Solomon Islands. Antiquity 66:898-912.

Medway, Lord

1977 The wild pig remains from the West Mouth, Niah Cave. Sarawak Museum Journal 25 (n.s. 46) :21-39.

Pavlides, Christina, and Chris Gosden

199435,000 year old sites in the rainforests of New Britain, Papua New Guinea. Antiquity $68: 604-610$.

Payne, J., C. M. Francis, and K. Phillips

1994 A Field Guide to the Mammals of Borneo, 2nd ed. Kota Kinabalu: Sabah Society.

Piperno, Dolores R., and Deborah M. Pearsall

1998 The Origins of Agriculture in the Lowland Neotropics. London: Academic Press.

Piperno, Dolores R., A. J. Ranere, Irene Holst, and P. Hansell

2000 Starch granules reveal early root crop horticulture in the Panamanian tropical forest. Nature 407 : 894-897.

PURI, R. K.

1997 Penan Benalui knowledge and use of tree palms. In People and Plants of Kayan Mentarang: 125-225, eds. K. W. Sorenson and B. Morris. London: WWF-IP/UNESCO.

Richards, ANTHONY

1981 An Iban-English Dictionary. Oxford: Chambers Press.

RICHARDS, P. W.

1996 The Tropical Rainforest, 2nd ed. Cambridge: Cambridge University Press.

Shafer, H. J., AND R. G. Holloway

1979 Organic residue analysis in determining stone tool function. In Lithic Use-Wear Analysis: 385-399, ed. B. Hayden. London: Academic Press.

SHUJI, YoshidA

2002 Wild food plants and vegeculture, in Vegeculture in Eastern Asia and Oceania: 31-44, ed. Y. Shuji and P. J. Mathews. JCAS Symposium Series 16. Osaka: National Museum of Ethnology.

Sun, Xianguun, X. Li, and X. D. Chen

2000 The vegetation and climate at the last glaciation on the emerged continental shelf on the South China Sea. Palaeogeography, Palaeoclimatology, Palaeoecology 160:301-316.

Therin, Michael J.

1994 Subsistence through Starch: The Examination of Subsistence Changes on Garua Island, West New Britain, PNG, through the Extraction and Identification of Starch in Sediments. B.A. thesis. University of Sydney, Sydney.

Therin, Michael, Richard Fullagar, and Robin Torrence

1999 Starch in sediments: A new approach to the study of subsistence and land use in Papua New Guinea. In Prehistory of Food: 438-462, ed. C. Gosden and J. Hather. London: Routledge.

TOWNSEND, Patricia K.

1990 On the possibility/impossibility of tropical forest hunting and gathering. American Anthropologist $92: 745-747$.

Ugent, Don, and L. W. Peterson

1988 Archaeological remains of potato and sweet potato in Peru. CIP Circular 16:1-9.

Uhl, Natalie W., and John Dransfield

1987 Genera Palmarum. Lawrence, KS: Allen Press.

Ulijaszek, Stanley J., and Simon P. Poraituk

1993 Making sago in Papua New Guinea: Is it worth the effort? In Tropical Forests, People and Food: 271-280, ed. C. M. Hladik, A. Hladik, O. F. Linares, H. Pagezy, A. Semple, and M. Hadley. Paris: UNESCO. 
Voris, Harold K.

2000 Maps of Pleistocene sea levels in Southeast Asia: Shorelines, river systems and time durations. Journal of Biogeography 27:1153-1167.

Yen, Douglas E.

1995 The development of Sahul agriculture with Australia as bystander. Antiquity 69:831-847.

\section{ABSTRACT}

A study of preserved starch grains from sedimentary sequences at Niah Cave, Sarawak, Borneo, reveals direct evidence for the use of rainforest plants rich in digestible carbohydrates. Plants identified include several species of Aroids (Alocasia sp., Cyrtosperma sp.), at least one species of yam (Dioscorea sp.), and the pith of sago palm (cf. Caryota mitis, Eugeissona utilis). Starch grains from a total of fourteen recurring types indicate that a wide range of starch-rich plants are present in Pleistocene occupation sediments from the cave, and await identification with a more comprehensive reference collection of tropical species. The technique of starch extraction from archaeological sediments presents archaeologists with a new and powerful tool for investigating the past diet of tropical forest hunter-gatherers. KEYwORDs: starch, starch grains, foraging, rainforest, tubers, palm sago. 